\title{
Real-time monitoring of nitrate transport in the deep vadose zone under a crop field - implications for groundwater protection
}

\author{
Tuvia Turkeltaub ${ }^{1}$, Daniel Kurtzman ${ }^{2}$, and Ofer Dahan ${ }^{1}$ \\ ${ }^{1}$ Department of Hydrology \& Microbiology, Zuckerberg Institute for Water Research, Blaustein Institutes for \\ Desert Research, Ben Gurion University of the Negev, Sde Boker Campus, Negev 84990, Israel \\ ${ }^{2}$ Institute of Soil, Water and Environmental Sciences, The Volcani Center, Agricultural Research Organization, \\ P.O. Box 6, Bet Dagan 50250, Israel \\ Correspondence to: T. Turkeltaub (tuviat@post.bgu.ac.il)
}

Received: 9 February 2016 - Published in Hydrol. Earth Syst. Sci. Discuss.: 16 February 2016

Revised: 1 July 2016 - Accepted: 12 July 2016 - Published: 2 August 2016

\begin{abstract}
Nitrate is considered the most common non-point pollutant in groundwater. It is often attributed to agricultural management, when excess application of nitrogen fertilizer leaches below the root zone and is eventually transported as nitrate through the unsaturated zone to the water table. A lag time of years to decades between processes occurring in the root zone and their final imprint on groundwater quality prevents proper decision-making on land use and groundwaterresource management. This study implemented the vadosezone monitoring system (VMS) under a commercial crop field. Data obtained by the VMS for 6 years allowed, for the first time known to us, a unique detailed tracking of water percolation and nitrate migration from the surface through the entire vadose zone to the water table at $18.5 \mathrm{~m}$ depth. A nitrate concentration time series, which varied with time and depth, revealed - in real time - a major pulse of nitrate mass propagating down through the vadose zone from the root zone toward the water table. Analysis of stable nitrate isotopes indicated that manure is the prevalent source of nitrate in the deep vadose zone and that nitrogen transformation processes have little effect on nitrate isotopic signature. The total nitrogen mass calculations emphasized the nitrate mass migration towards the water table. Furthermore, the simulated pore-water velocity through analytical solution of the convection-dispersion equation shows that nitrate migration time from land surface to groundwater is relatively rapid, approximately 5.9 years. Ultimately, agricultural land uses, which are constrained to high nitrogen application rates and coarse soil texture, are prone to inducing substantial nitrate leaching.
\end{abstract}

\section{Introduction}

Groundwater contamination by nitrate originating from agricultural land use is a global problem. The World Health Organization guideline for maximum level of nitrate in the drinking water is $50 \mathrm{mg} \mathrm{L}^{-1}$ as $\mathrm{NO}_{3}$ (WHO, 2011). The US Environmental Protection Agency (EPA) regards nitrate as requiring immediate action whenever its concentration exceeds drinking-water standards (US EPA, 1994). A detailed framework was established by the Nitrate Directive of the EC (European Community, 1991) to prevent water pollution by nitrate. Nevertheless, nitrate contamination has disqualified drinking-water wells in Israel (local standard: $70 \mathrm{mg} \mathrm{L}^{-1}$ $\mathrm{NO}_{3}$ ) more than any other contaminant at the beginning of the 21st century (Elhanany, 2009). To prevent excessive leaching of nitrate and its arrival in the groundwater, it is essential to investigate and quantify the mechanisms controlling nitrate migration in the unsaturated zone with respect to the specific practices used on agricultural land.

Nitrate fate in the subsurface has been investigated by various approaches, such as (i) isotopic signature analysis in groundwater systems (Oren et al, 2004; Wassenaar et al., 2006; Showers et al., 2008; Baram et al., 2013), (ii) cropmanagement strategies, which combine crop production and nitrate leaching to the subsurface (Hanson et al., 2006; Doltra and Muñoz, 2010; Beggs et al., 2011), and (iii) studies based on data from the deep vadose zone (Dann et al., 2010; Nolan et al., 2010; Botros et al., 2012; Kurtzman et al., 2013; Dahan et al., 2014; Turkeltaub et al., 2015b). Nevertheless, estimates based on data obtained from excavated soil profiles 
and pore-water sampling during a short period of time represent a snapshot in time of the sediment's chemical state rather than dynamic temporal variations. Moreover, the drawback of methods based on frequent groundwater sampling from wells is that the concentration of nitrate might already be at levels that will lead to disqualification of the aquifer as a source of drinking water.

The transfer time of nitrate within the deep vadose zone has been estimated to take weeks to decades, depending on the water regime, thickness of the unsaturated zone and lithological characteristics of the subsurface (Spalding et al., 2001; Scanlon et al., 2010). Knowledge of nitrate's fate and transport below the root zone is restricted due to issues such as soil spatial variability and long travel times in the deep vadose zone (Onsoy et al., 2005). Moreover, estimates of cumulative nitrate fluxes in the unsaturated zone have shown significant differences in the timing and magnitude of fluxes derived from different land uses (Green et al., 2008; Dahan et al., 2014; Turkeltaub et al., 2014, 2015b). Our understanding of the cumulative effect of nitrate leaching from the root zone through the unsaturated zone on nitrate levels in the groundwater is blurred by mixing and dilution in the aquifer water. The tendency toward elevated nitrate concentration in aquifer water is thus a relatively slow process (Green et al., 2008). Knowing the time lag between initiation of a pollution process in the unsaturated zone and its final effect on aquifer quality could give decision-makers more time to plan possible backups for alternative water supply (Baram et al., 2014).

The recent development of a vadose-zone monitoring system (VMS) enables continuous monitoring of the hydrological and chemical properties of percolating water in the deep vadose zone under agriculture settings (Turkeltaub et al., 2014, 2015b) and other hydrological settings (e.g., Dahan et al., 2009; Baram et al., 2013). Data collected by the system comprise direct measurements of the water-percolation fluxes and the chemical evolution of the percolating water across the entire unsaturated zone. An earlier investigation at the present study site implemented the VMS and demonstrated the percolation patterns, chloride accumulation and groundwater recharge behavior and tendency in the deep vadose zone of two agricultural settings, a grapefruit orchard and a crop field (Turkeltaub et al., 2014). Unsaturated flow models were calibrated to the water content observation and were used for groundwater recharge flux simulations.

The objective of the present study was to demonstrate the water flow and nitrate transport through the deep vadose zone underlying the crop field, with respect to rain patterns as well as the agricultural and fertilization setup. Continuous data on variations in the sediment water content and nitrate concentrations were collected from the entire vadose zone for over 6 years. The nitrate concentration time series, which included variations of nitrate in time and at multiple depths, revealed, in real time, a major pulse of nitrate mass propagating down through the vadose zone toward the water table. These results indicate that nitrate fluxes in the unsaturated zone underlying

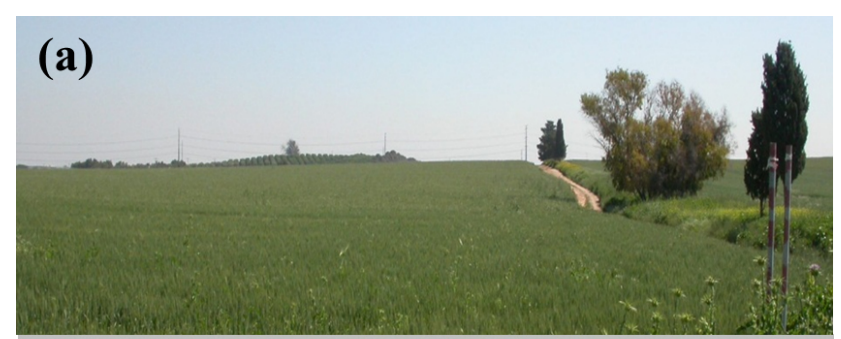

(b)

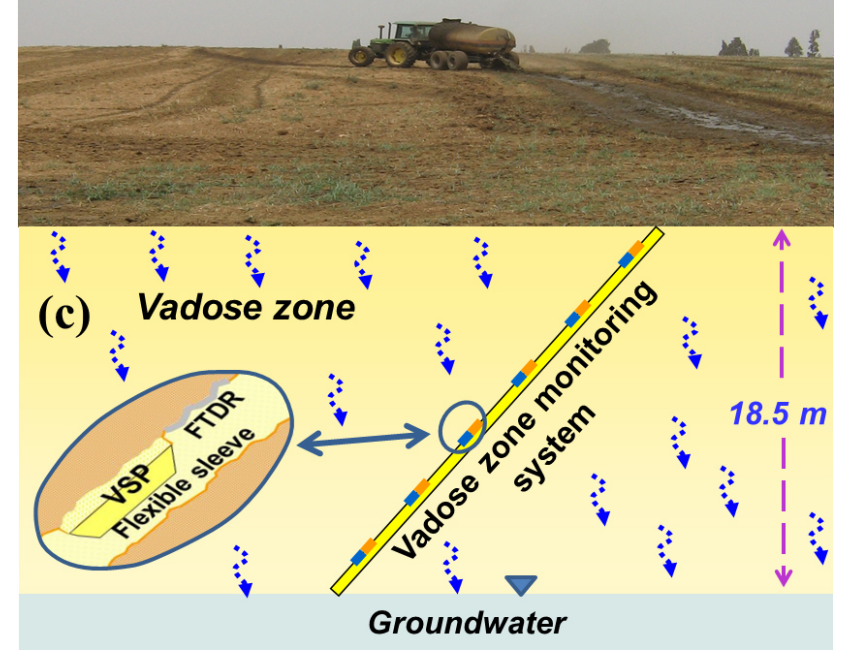

Figure 1. Crop field site with monitoring location during two periods: crop growth during the wet season (a), and after harvesting and during slurry application (b). (c) Schematic illustration of the vadose-zone monitoring system installed under the crop field. VSP, vadose-zone sampling port; FTDR, flexible time-domain reflectometry sensor.

agriculture land uses were associated with high nitrogen application rates and coarse-textured soils. Furthermore, pollution events that originated from agriculture land uses can be monitored in their early stages, long before pollution accumulates in the aquifer water.

\section{Methods}

\subsection{Study area}

A commercial crop field site was selected as a representative prevalent agriculture setting in the southern part of the coastal plain of Israel $\left(34^{\circ} 41^{\prime} 13^{\prime \prime} \mathrm{E} ; 31^{\circ} 49^{\prime} 42^{\prime \prime} \mathrm{N}\right)$ and is part of an array of VMSs that were installed under different representative land uses situated above the southern part of the phreatic costal aquifer (Dahan et al., 2014; Baram et al., 2013, 2014; Turkeltaub et al., 2014, 2015a, b). The study was conducted between September 2009 and April 2015. A Mediterranean climate prevails in this area, with hot, dry summers (May-September) and rainy winters (OctoberApril), with an average annual rainfall of $512 \mathrm{~mm}$ and aver- 
Table 1. Depth distribution of the vadose-zone monitoring system (VMS) units.

\begin{tabular}{cc}
\hline \multicolumn{2}{c}{$\begin{array}{c}\text { Vertical depth } \\
\text { from land surface }(\mathrm{m})\end{array}$} \\
\hline $\begin{array}{c}\text { Vadose-zone } \\
\text { sampling port }\end{array}$ & FTDR $^{1 *}$ \\
\hline 1 & 0.5 \\
2.7 & 2.1 \\
4.2 & 3.1 \\
6.3 & 5.7 \\
9.5 & 8.9 \\
12.6 & 12 \\
15.7 & 15.1 \\
18 & 17.4 \\
\hline * Flexible time-domain reflectometry \\
probe.
\end{tabular}

age temperatures of $31.2^{\circ} \mathrm{C}$ (August) and $17.8^{\circ} \mathrm{C}$ (January) in the hottest and coldest months, respectively (Israeli Meteorological Service, 2015). Reference evapotranspiration rates calculated according to the Penman-Monteith method (suggested by the Food and Agriculture Organization) range from $1.5 \mathrm{~mm} \mathrm{day}^{-1}$ (January) to $5.7 \mathrm{~mm} \mathrm{day}^{-1}$ (July; Israeli Meteorological Service, 2015).

The crop field cultivation history includes alternation between rainfed agriculture as wheat and irrigated agriculture as watermelon for seeds and cotton as summer crop (personal communication). From 2005 to 2013, the crop field site was cultivated with rainfed winter crops-spring wheat (Triticum aestivum L.) and pea (Pisum sativum L.; Fig. 1). Then, for 1 year (2013/2014), the field was uncultivated. The crops were sown at the beginning of the wet season (November) and grew into the spring (April). After harvest, disk plow and roller practices were implemented. Since 2005, the main fertilization application to the field was dairy-farm slurry manure, which was distributed over the 10 ha field for 60 days during May and June (Fig. 1). The total nitrogen concentration in the dairy slurry is $900 \mathrm{mg} \mathrm{L}^{-1}$ (Israel Water Authority, 2012). In September 2014, jojoba (Simmondsia chinensis) shrubs were planted and irrigation systems were installed.

\subsection{Monitoring}

The field was instrumented with a VMS in May 2008 (Fig. 1). Full technical descriptions of the VMS structure, performance and installation procedures can be found in other publications (Rimon et al., 2007, 2011; Dahan et al., 2008, 2009). For brevity, only a general description is given here.

The VMS is composed of a flexible sleeve installed in an uncased, slanted $\left(35^{\circ}\right.$ to the vertical) borehole hosting multiple monitoring units at various depths. Each monitoring unit consisted of a flexible time-domain reflectometry (FTDR) sensor for continuous measurements of sediment water content and a vadose-zone sampling port for frequent collection of pore-water samples from the unsaturated zone (Table 1). The slanted installation ensures that each monitoring unit faces an undisturbed sediment column that extends from the land surface to the probe or sampling port depth. After insertion of the VMS into the borehole, the flexible sleeve was filled with a high-density solidifying material (liquid twocomponent urethane) that solidifies in the borehole shortly after its application, thereby ensuring proper sleeve expansion for good contact of the monitoring units with the borehole's irregular walls, sealing its entire void and preventing potential cross-contamination by preferential flow along the borehole.

Since each monitoring unit is located under its own undisturbed sediment column, the integrated data from the VMS should be regarded as representative of a wider zone rather than a single vertical profile. Sediment water content was monitored daily. Pore-water sampling from the unsaturated sediments is achieved by creating hydraulic continuity between the sediment and the sampling port using a flexible porous interface (Dahan et al., 2009; patent no. US 6956381 ; US 12/222,069; EP 07706061.4; IL 193126). The vadosezone sampling ports (VSPs) are operated through a set of small-diameter access tubes and control valves. Prior the water sampling collection, a low-pressure (vacuum) is applied to the sampling ports to draw the sediment pore water. Subsequently, the water samples are retrieved using pressurized gas $\left(\mathrm{N}_{2}\right)$ to push the sample to the surface. Water samples were collected every 90 days on average, from September 2009 to April 2015. Samples were stored chilled in the field and at $4{ }^{\circ} \mathrm{C}$ in the laboratory after being filtered through a $45 \mu \mathrm{m}$ filter. Chemical analyses were performed the following day. The monitoring system operated with Campbell Scientific (Logan, UT) data acquisition and logging instruments, including TDR100, SDM50X, AM 16/32 multiplexers and a CR10X datalogger.

\subsection{Chemical and isotopic analyses}

Nitrate and chloride concentrations in the water samples were determined using ion chromatography (DIONEX, 4500I). The isotopic composition of nitrate $15 \mathrm{~N}$ and $18 \mathrm{O}$ in the water samples was determined through nitrate reduction to nitrogen dioxide, which was then analyzed using a gas mass spectrometer (Mcllvin and Altabet, 2005).

\subsection{Nitrate transport simulations}

The observed nitrate concentration dynamics at the 6.3, 9.5, 15.6 and $18 \mathrm{~m}$ depths (Table 1) were analyzed and compared with earlier modeling estimations conducted according to observations of water content under the crop field (Turkeltaub et al., 2014). Nitrate transport was modeled in terms of the convection-dispersion equation (CDE) equilibrium assum- 
ing resident concentration for a third-type inlet condition as follows (Toride et al., 1999):

$R \frac{\partial c}{\partial t}=D \frac{\partial^{2} c}{\partial x^{2}}-v \frac{\partial c}{\partial x}$,

where $c$ is the solute concentration, $x$ is distance, $t$ is time, $D$ is the dispersion coefficient, $v$ is the average pore-water velocity (water flux $q$ divided by the water content $\theta$ ), and $R$ is the retardation factor.

The nitrate concentrations obtained by the VSP at $4.2 \mathrm{~m}$ depth (Table 1) served as a series of successive applications of solute pulses (multi-pulse boundary condition). All of the sampling ports are located in a relatively homogeneous medium of sandy texture (Turkeltaub et al., 2014), following the intrinsic assumption of CDE analytical model homogeneity. The CXTFIT2 code (Toride et al., 1999) and the Levenberg-Marquardt-type optimization approach (Marquardt, 1963), both included in STANMOD (van Genuchten et al., 2012), were used for inversely estimating the porewater velocity $(v)$ and dispersion coefficient $(D)$ according to observed concentrations. Both parameters were obtained by running CXTFIT2 multiple times for inverse optimization, each time with different initial values (Turkeltaub et al., 2015a, b).

\subsection{Total nitrate mass}

The total nitrate mass in the unsaturated zone estimations was calculated to emphasize the nitrate mass that will eventually contaminate the groundwater. The following equation was used for yearly nitrate mass (per area) in the vadose zone:

$$
M=\int_{Z=\text { water_table }}^{Z=\text { ground_surface }} \overline{\theta_{i}} \times C_{i} \times \mathrm{d} z_{i},
$$

where $M$ is nitrate mass in the vadose zone under a unit area, $i$ indexes the depth interval for which the corresponding sampling port is at its center, $C_{i}$ is the nitrate concentration $\left(\mathrm{ML}^{-3}\right)$ sampled with the sampling port at that depth interval, $\theta i$ is the average water content measured by the nearest FTDR sensor $\left(\mathrm{L}^{3} \mathrm{~L}^{-3}\right)$, and $\mathrm{d} z_{i}$ is the interval length (L) (Fig. 2).

\section{Results and discussion}

\subsection{Nitrate migration in the unsaturated zone}

The continuous monitoring of the vadose zone shows temporal variations in measured water content (Fig. 2). Throughout the monitoring period, most of the rainstorms caused a rise in the water content measured by the shallowest water sensor ( $0.5 \mathrm{~m}$, Fig. 2). At the 2.1 and $3.1 \mathrm{~m}$ depths, the rise in water contents corresponded mainly to larger rain events (Fig. 2b, c). The sensors at the deeper depths displayed temporal variability with respect to the cumulative annual rain pattern. In some years, a lag between the end of the rainy season and the rise in water content was recorded, whereas in other years, the rise in water content occurred throughout the entire vadose zone following a significant rain event (Fig. $2 \mathrm{~d}-\mathrm{h}$ ). A more detailed description of the sequential rise in water content with depth following a wetting event on land surface, and a clear indication of propagation of a wetting wave through the vadose zone, are presented in our earlier study at the site (Turkeltaub et al., 2014) and in other studies at different sites (Rimon et al., 2007, 2011; Dahan et al., 2008, 2009; Baram et al., 2012, 2013).

Throughout 6 years of continuous monitoring, variations in nitrate concentration were observed (Fig. 3). The nitrate concentration time series with depth (Fig. 3) reveals a major pulse of elevated concentrations, initiating close to the surface in 2011 and 2012, and gradually progressing down the vadose zone toward the water table at a depth of about $18 \mathrm{~m}$. The process was first monitored at the uppermost sampling port at $1 \mathrm{~m}$ depth, where nitrate concentrations displayed a significant increase during the winter of 2010/2011. Then a gradual trend of reduction in nitrate concentration was observed at this depth until March 2014. A close examination of the nitrate concentrations at $1 \mathrm{~m}$ depth indicated repeating fluctuations, with higher nitrate concentrations after harvest due to application of the dairy slurry, and then followed by a reduction in concentrations. Although hard to notice at the illustrated scale in Fig. 3a, the nitrate concentrations between September 2009 and September 2010 were still relatively high and fluctuated near $600 \mathrm{mg} \mathrm{L}^{-1}$ (Fig. 3a). Then they escalated to about $3200 \mathrm{mg} \mathrm{L}^{-1}$ after cultivation of the pea crop. Following this relatively large increase in nitrate concentration in May 2011, a decline was observed until January 2012 to about $1500 \mathrm{mg} \mathrm{L}^{-1}$ (Fig. 3a). This phenomenon repeated itself in April 2012, when the nitrate concentration increased again to $2800 \mathrm{mg} \mathrm{L}^{-1}$ and then decreased to $78 \mathrm{mg} \mathrm{L}^{-1}$ in April 2015 due to cessation of slurry application (Fig. 3a; note the solid line arrow).

The distributed estimated nitrogen mass over the field is approximately $200 \mathrm{Kg} \mathrm{ha}^{-1} \mathrm{yr}^{-1}$, which is in the range of the European application recommendations (van Grinsven et al., 2012). The Agriculture Extension Service of Israel (2016) recommendation concerning nitrogen fertilizer application for wheat crop (main crop) is between 40 and $100 \mathrm{~kg} \mathrm{ha}^{-1}$. Therefore, an excessive amount of nitrogen is applied by disposing of dairy wastes over the field. Moreover, nitrogen fixing agents in agricultural systems are the symbiotic associations between legumes and rhizobia (Rochester et al., 2001). Rotation between legume crop and non-legume crop practice supposes to replace some of the need for nitrogen fertilizer (Rochester et al., 2001). The average nitrogen fixation by pea crop, according to global data sets, is $86 \mathrm{Kg} \mathrm{ha}^{-1} \mathrm{yr}^{-1}$ (Herridge et al., 2008), which is about $43 \%$ of the nitrogen applied by the dairy slurry. Thus, application of dairy farm 

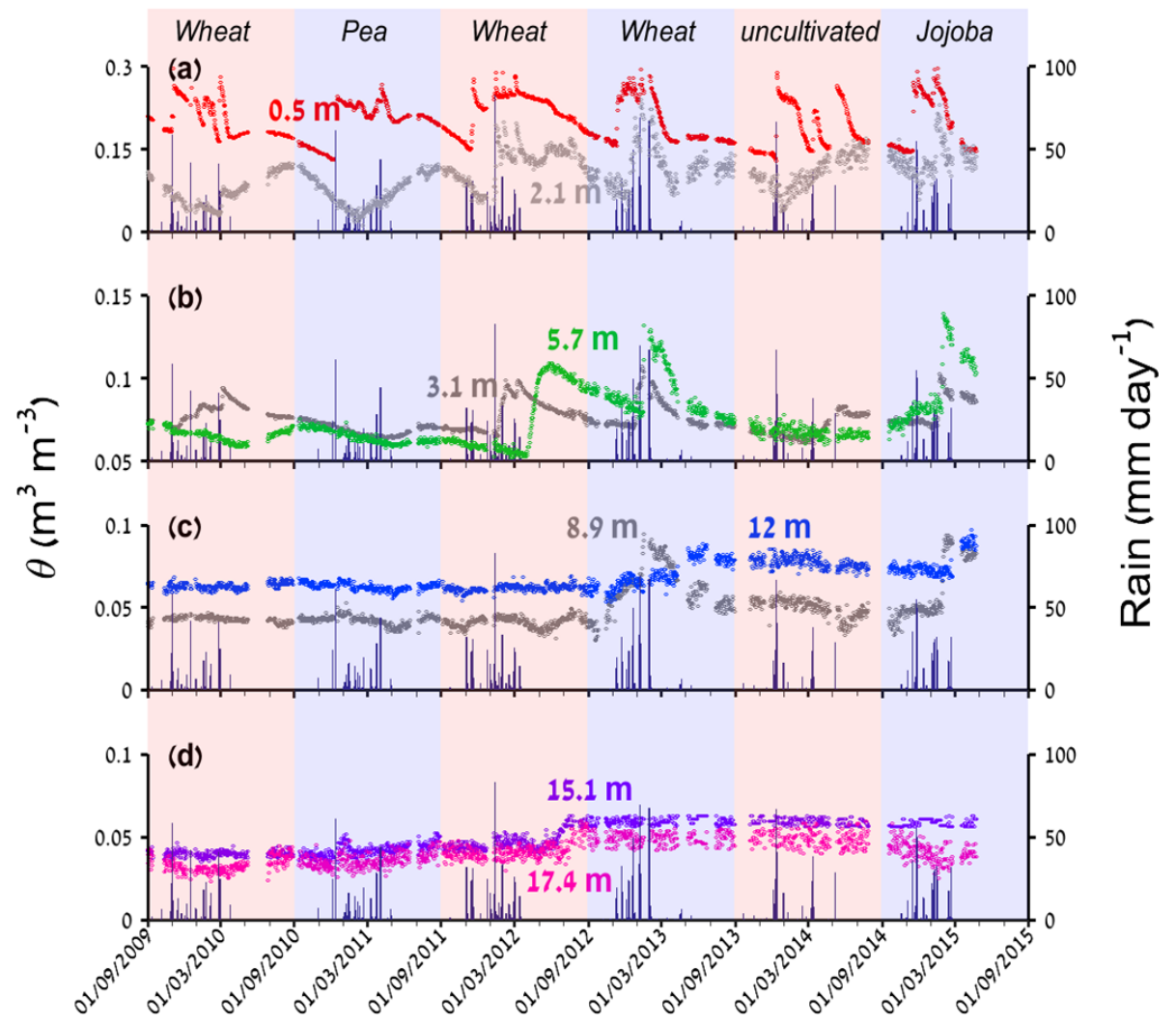

Figure 2. Water content $(\theta)$ at different depths in the vadose zone and daily rainfall for 6 consecutive years.

slurry combined with a legume crop (pea) seemed to have enriched the top soil with excess nitrogen, as compared to cultivation of cereal-type crops (Fig. 3a).

Progression of the nitrate migration deeper into the vadose zone can be divided into two periods. In the first period, October 2010 to January 2013, at depths of 2.7, 4.2, 9.5 and $15.6 \mathrm{~m}$ (Fig. 3b, c, e, g), the increase in nitrate concentration was moderate and continuous, whereas, at depths of 6.3 and $18 \mathrm{~m}$, there was no major change in nitrate concentrations (Fig. 3b-d). In the second period, starting from July 2013 following the rainy winter of 2012/13, substantial nitrate breakthroughs were noticeable throughout most of the vadose-zone cross section (marked with arrows in Fig. 3). This rapid nitrate progression to the deeper parts of the vadose zone could be related to the soil's physical characteristics. In the top $3 \mathrm{~m}$, the soil comprised of fine-textured layers (sandy loam and loamy sand), and from 3 to $18.5 \mathrm{~m}$ (water table), the soil consisted of a coarser sand-textured layer (Turkeltaub et al., 2014). Thus, as a consequence of substantial water percolation, which induced intensive water flux across the coarse-textured soil, nitrate transport could be detected at deeper depths of the vadose zone.

Here, as well as in previous studies in the literature, nitrate fluxes in the unsaturated zone underlying agricultural land uses were associated with nitrogen application rates and soil physical properties (Green et al., 2008; Botros et al.,
2012; Turkeltaub et al., 2015b). Therefore, to attenuate nitrate leaching to aquifers, a search should be dedicated to locate the "hot spots" where these conditions prevailed (Liao et al., 2012).

\subsection{Nitrate sources}

The $\delta^{15} \mathrm{~N}$ values clearly showed that manure is the main source of nitrate in the vadose-zone pore water (Fig. 4). Nitrate isotope composition in the vadose-zone pore water depends on nitrogen sources and transformation processes (Böhlke, 2002). Examination of the isotope values suggested that transformation processes such as denitrification and mineralization of soil nitrogen sources have little effect on nitrate isotopic signature. As discussed in the previous section, the relatively rapid nitrate transport downward to deeper parts of the vadose zone is controlled by soil properties and nitrogen application rates. These factors reduce the potential for transformation processes and plant uptake to occur (Liao et al., 2012). Moreover, various studies conducted under similar conditions (soil types and agriculture land use) to in the current study presented insignificant nitrogen transformation processes and doubt the ability to attenuate nitrate within the deeper vadose zone (Green et al., 2008; Burow et al., 2010; Gautam and Iqbal, 2010; Dann et al., 2013; Zhang et al., 2014; Turkeltaub et al., 2015b). However, other studies sug- 

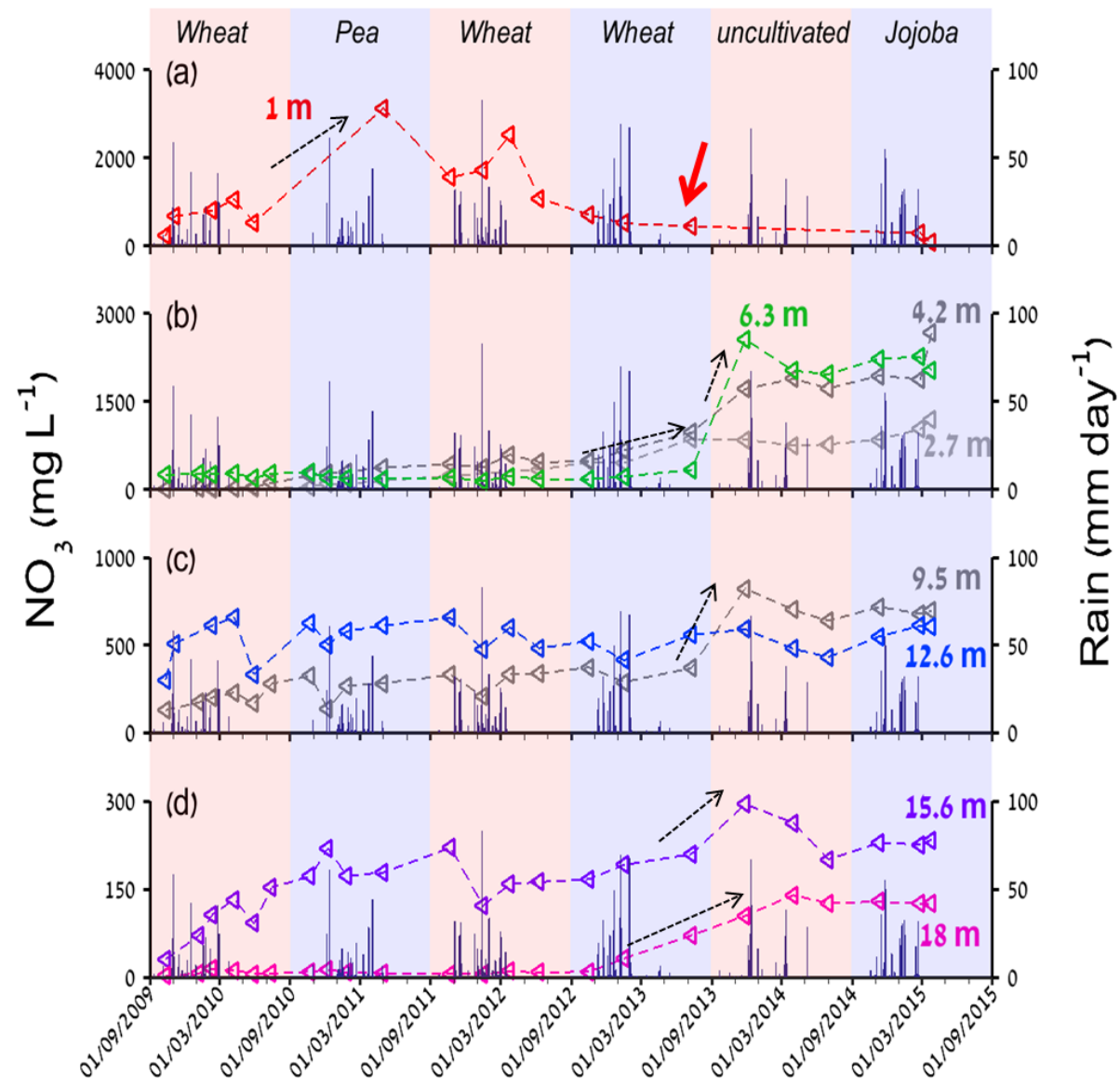

Figure 3. Time series of observed $\left(\mathrm{NO}_{3}\right)$ concentrations in the vadose zone and daily rainfall for 6 consecutive years.

gested contrasting conclusions. Salazar et al. (2012) reported on low nitrate leaching rates in spite of high nitrogen application rates and Lockhart et al. (2013) claimed that depth to groundwater provided a significant control on nitrate concentration in groundwater regardless of soil type or crop type. Thus, a holistic approach comprising all potential factors that control nitrate fluxes to groundwater should be taken to identify the dominant ones.

\subsection{Nitrate storage in the vadose zone}

The yearly nitrate mass calculations (Eq. 2) displayed an increase from 2009 to 2010 (Fig. 5), at the same time as $\mathrm{NO}_{3}$ concentration increased in the upper part of the vadose zone (Fig. 3a). Subsequently, the highest increase in nitrate mass was calculated for 2011 following the combination of cultivation of the pea crop and excessive application of dairy slurry (Fig. 5). It seems that the yearly fluctuations in calculated nitrate mass can be explained by the lag time in the transport process between the sampling points. Hence, the peak in nitrate mass observed in the upper parts during 2011 remained in the vadose cross section and eventually reached the deeper parts of the vadose zone as a breakthrough type (Fig. 5).

\subsection{Nitrate transport model}

Using nitrate time series obtained from the deeper part of the vadose zone for model simulations allowed one to avoid the highly dynamic nature of the root zone. Furthermore, transport calculations are less affected by mass balance uncertainties as, according to previous section, nitrate attenuation processes are insignificant in the deep vadose zone.

The results indicated relatively good agreement between observed and simulated nitrate concentration trends (Fig. 6). Nevertheless there were discrepancies in the absolute values and in the simulated nitrate concentrations increasing before the observed concentrations at the 6.3 and $18 \mathrm{~m}$ depths (Fig. 6a, d). These gaps could be explained by the assumptions that are intrinsic to the CDE model (Eq. 1) - homogeneous medium and average velocity - along with the assumption of even distribution of the nitrogen source on the surface. Nevertheless, the CDE provided an approximation that could be compared with earlier numerical modeling results (van Genuchten et al., 2012). The calculated hydrodynamic 


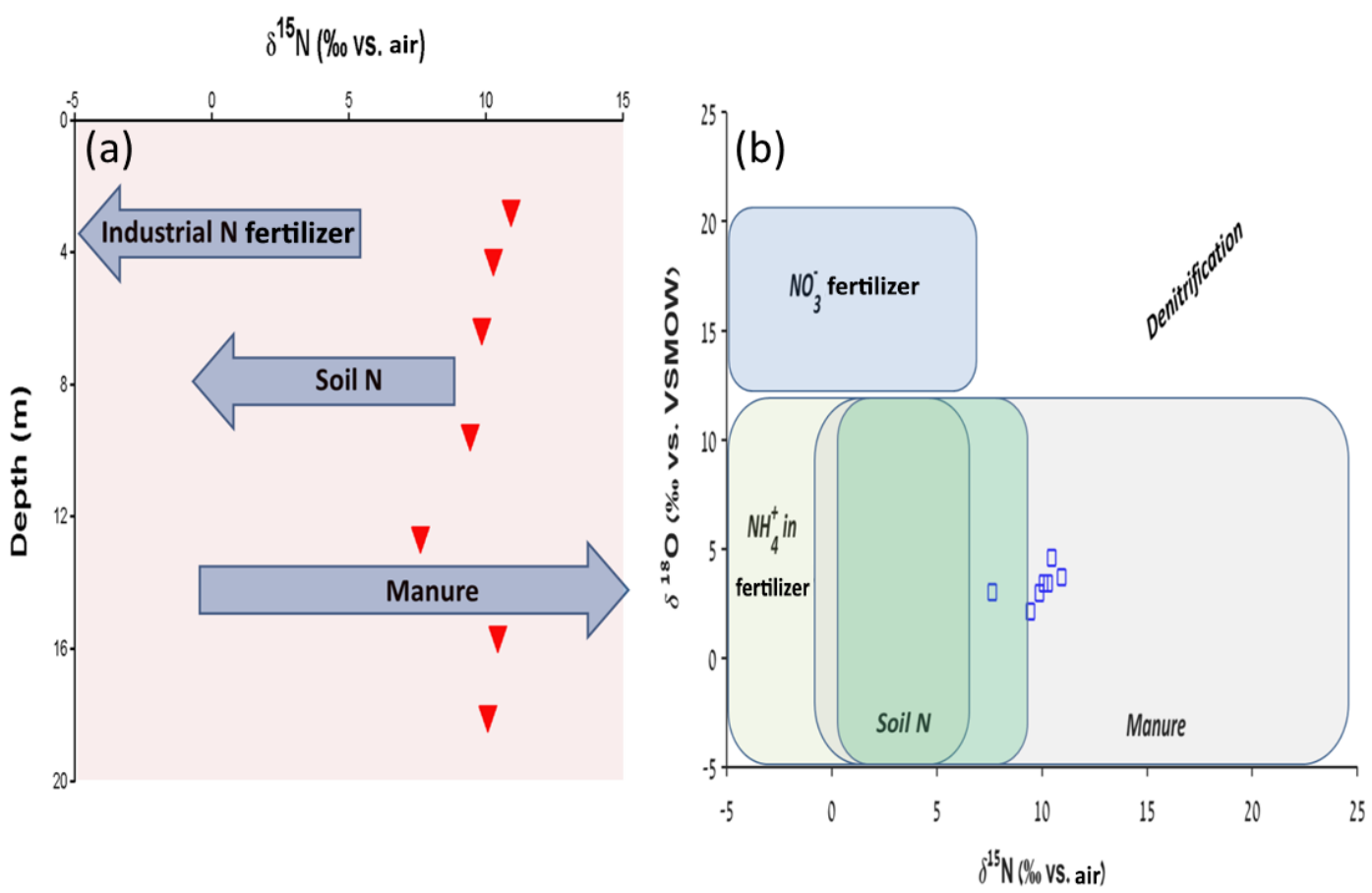

Figure 4. $\delta^{15} \mathrm{~N}$ profile of nitrate in the water samples obtained from the vadose zone under the crop field.

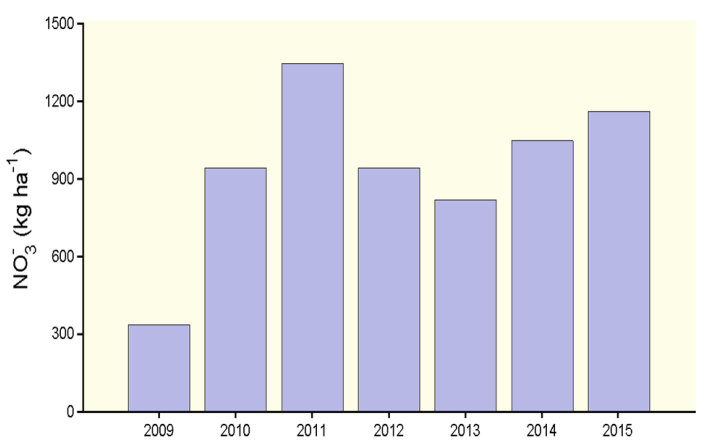

Figure 5. Yearly total nitrate mass of the entire vadose zone per year of sampling.

dispersion coefficient was $81 \mathrm{~cm}^{2}$ day $^{-1}$ and the pore-water velocity was $0.836 \mathrm{~cm} \mathrm{day}^{-1}$, which is about $305 \mathrm{~cm} \mathrm{yr}^{-1}$. Multiplying the velocity by the weighted average water content, $0.060 \mathrm{~cm}^{3} \mathrm{~cm}^{-3}$ (Fig. 2c-h), the Darcian flux equaled $18.3 \mathrm{~cm} \mathrm{yr}^{-1}$, which is very similar to the earlier average flux estimation of $19.9 \mathrm{~cm} \mathrm{yr}^{-1}$ averaged for 24 years (Turkeltaub et al., 2014). When neglecting the diffusion term in the hydrodynamic dispersion coefficient, the estimated longitudinal dispersivity $(D / v)$ is $97 \mathrm{~cm}$. The calculated dispersivity value is relatively large compared with reported values from earlier solute transport investigations in sandy texture soils (e.g., Toride et al., 2003; Dann et al., 2010). However, it was shown that dispersivity increases with travel distance (Vanderborght and Vereecken, 2007).
The calculated nitrate transport time from land surface to groundwater is approximately 5.9 years. However, the increase in nitrate concentration at $18 \mathrm{~m}$ depth occurred in July 2013 , which is 8 years after the first slurry application. Olson et al. (2009) reported that there was a threshold amount of slurry application before nitrate accumulated in the soil. Hence, the gap of 2 years between the first application and nitrate arrival at $18 \mathrm{~m}$ depth might be related to the period before a critical amount of manure was applied to the field.

\subsection{Practical implications of vadose-zone monitoring}

To prevent a long-term gradual degradation in groundwater quality, the link between sources of pollution on the surface and their migration pattern in the unsaturated zone should be understood long before their final cumulative imprint in the aquifer water. Herein, the application of a VMS under an agricultural field enabled, for the first time known to us, real-time tracking of water flow and nitrate transport from the surface through the entire deep vadose zone. Accordingly similar monitoring concepts for the vadose zone can be used as an alert apparatus for pollution events in their early stages while pollution is still migrating in the unsaturated zone, and long before accumulation in the aquifer water.

This study demonstrates how nitrate concentrations in the vadose zone exceed the local standard for disqualified drinking-water wells and threaten the groundwater quality. Hence, agro-hydrologically sustainable manure application rates, i.e., sufficient crop production and minimization of nitrate leaching, could be satisfied by suitable regulation or ad- 


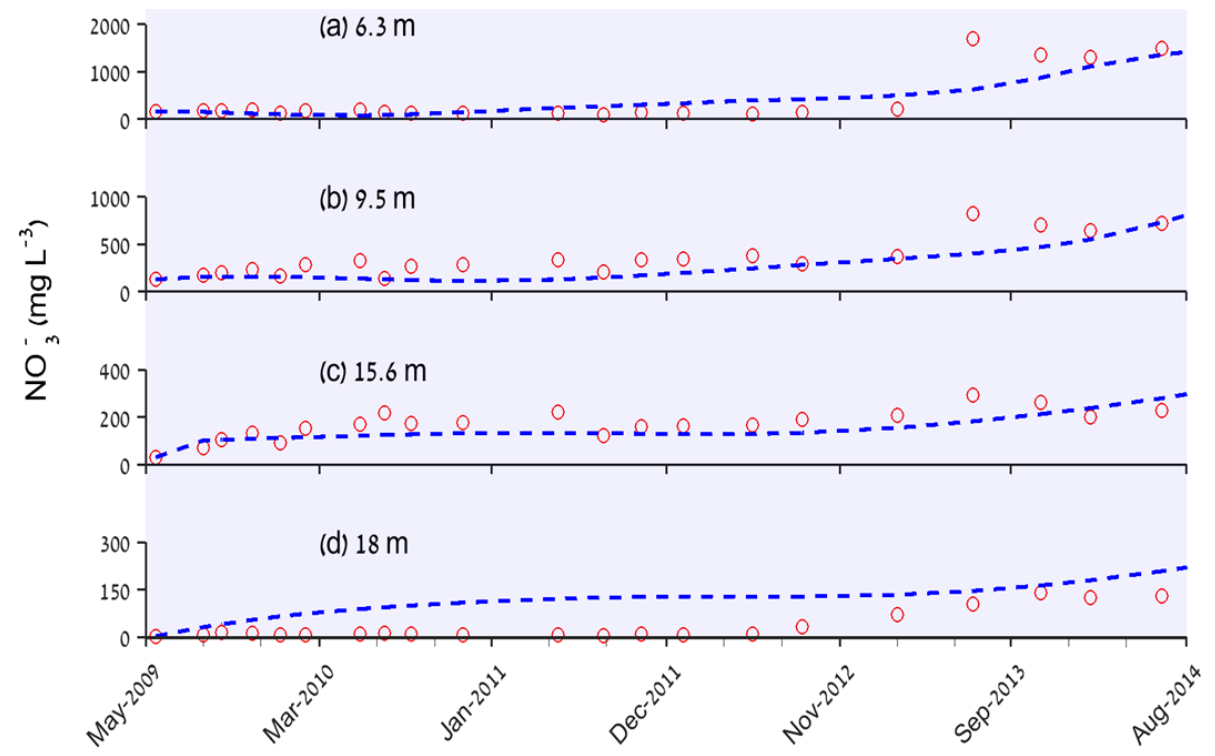

Figure 6. Observed (red dots) and simulated (dashed blue line) nitrate concentrations for the vadose-zone sampling port at the 6.3, 9.5, 15.6 and $18 \mathrm{~m}$ depths. Nitrate concentration series from each depth served as a multiple-pulse input boundary condition to the consecutive depth.

justments to meet crop requirements (Olson et al., 2010). To optimize the efficiency of the manure distribution methodology, estimations should include the controlling factors such as soil properties, crop type, season, nitrogen attenuation processes and the critical amount of manure application before nitrate accumulation in the soil occurs. Considering only some of the factors could lead to the opposite result. For example, the manure application in this study occurred during the beginning of the dry period, May and June (there are no rain events till October), to prevent nitrogen leaching due to rain events. However, the distributed nitrogen was retained in the soil till wintertime and did not undergo significant attenuation processes. The incorrect assumption of manure distribution during the dry period resulted in intensive nitrate leaching. Furthermore, according to the observations presented in this study, the manure application should be reduced following legume crop type. However, in many cases, there is a surplus amount of manure to be disposed of. Therefore, alternative methods for waste management have to be utilized, coinciding with regulation of manure application (Westerman and Bicudo, 2005; van Grinsven et al., 2012).

Nitrate transport from land surface to water table through a relatively thick vadose zone occurred within less than a decade. This is a considerably rapid pollutant migration when considering remediation strategies. Moreover, the nitrate observations obtained by the VMS and the isotopic signature analysis indicated that nitrate attenuation processes are insignificant. Hence, at agriculture sites constrained to similar conditions as in this study, most of the nitrate mass that leaches under the root zone will eventually reach groundwater.

\section{Summary and conclusions}

An intensive nitrate leaching beyond the root zone was attributed to soil properties and nitrogen application rates. The implementation of a vadose-zone monitoring system (VMS) under an agricultural field enabled real-time tracking of water flow and migration of a nitrate plume from the surface through the deep vadose zone to the water table at $18.5 \mathrm{~m}$ depth. Isotopic composition of nitrate-nitrogen in the water samples indicated that manure is the main nitrogen source of nitrate in the vadose-zone pore water. Nitrogen transformation processes seem to have only little effect under an intensively fertilized crop field. Total nitrate mass estimations displayed the nitrate mass advancement toward the deep vadose zone. Moreover, according to the simulated pore-water velocity, nitrate arrival at the water table occurred within less than a decade.

As in this study, an array of VMSs was installed under other representative agriculture land uses situated above the southern part of the Israeli costal aquifer. The findings from each site are combined to generate a comprehensive perspective of dominant factors controlling groundwater quality and quantities. Subsequently, these conclusions will be examined with a regional-scale aquifer transport model.

Protection of groundwater from potential pollution originating from agricultural land uses has to include effective and continuous monitoring of the vadose zone. Pollution events can be monitored in their early stages, long before pollution accumulates in the aquifer water.

Acknowledgements. This work was funded by the Israel Water Authority (no. 4500687174). Thanks go to Sara Elchanani and 
the Division of Water Quality of the Israel Water Authority for supporting and funding the project. We wish to express our gratitude to the farmers who allowed us to conduct this study in their fields. In addition, we would like to express our appreciation to Michael Kogel for his extensive effort in maintaining and operating the VMS. Data can be obtained by contacting the corresponding author.

Edited by: G. Fogg

Reviewed by: two anonymous referees

\section{References}

Agriculture Extension Service of Israel: Web of Ministry of Agriculture: Agricultural Extension Service of Israel, Shaham, Bet Dagan, available at: http://www.moag.gov.il/agri/English/ Ministrys1Units/Training1 and1Profession1Service/default.htm., last access: 18 March 2016.

Baram, S., Kurtzman, D., and Dahan, O.: Water percolation through a clayey vadose zone, J. Hydrol., 424-425, 165-171, doi:10.1016/j.jhydrol.2011.12.040, 2012.

Baram, S., Ronen, Z., Kurtzman, D., Külls, C., and Dahan, O.: Desiccation-crack-induced salinization in deep clay sediment, Hydrol. Earth Syst. Sci., 17, 1533-1545, doi:10.5194/hess-171533-2013, 2013.

Baram, S., Kurtzman, D., Ronen, Z., Peeters, A., and Dahan, O.: Assessing the impact of dairy waste lagoons on groundwater quality using a spatial analysis of vadose zone and groundwater information in a coastal phreatic aquifer, J. Environ. Manage., 132, 135-144, doi:10.1016/j.jenvman.2013.11.008, 2014.

Beggs, R. A., Hills, D. J., Tchobanoglous, G., and Hopmans, J. W.: Fate of nitrogen for subsurface drip dispersal of effluent from small wastewater systems, J. Contamin. Hydrol., 126, 19-28, doi:10.1016/j.jconhyd.2011.05.007, 2011.

Böhlke, J. K.: Groundwater recharge and agricultural contamination, Hydrogeol. J., 10, 153-179, 2002.

Botros, F. E., Onsoy, Y. S., Ginn, T. R., and Harter, T.: Richards equation-based modeling to estimate flow and nitrate transport in a deep alluvial vadose zone, Vadose Zone J., 11, doi:10.2136/vzj2011.0145, 2012.

Burow, K. R., Nolan, B. T., Rupert, M. G., and Dubrovsky, N. M.: Nitrate in groundwater of the United States, 1991-2003, Environ. Sci. Technol., 44, 4988-4997, doi:10.1021/es100546y, 2010.

Dahan, O., Tatarsky, B., Enzel, Y., Kulls, C., Seely, M., and Benito, G.: Dynamics of flood water infiltration and ground water recharge in hyperarid desert, Ground Water, 46, 450-461, doi:10.1111/j.1745-6584.2007.00414.x, 2008.

Dahan, O., Talby, R., Yechieli, Y., Adar, E., Lazarovitch, N., and Enzel, Y.: In situ monitoring of water percolation and solute transport using a vadose zone monitoring system, Vadose Zone J., 8, 916-925, doi:10.2136/vzj2008.0134, 2009.

Dahan, O., Babad, A., Lazarovitch, N., Russak, E. E., and Kurtzman, D.: Nitrate leaching from intensive o rganic farms to groundwater, Hydrol. Earth Syst. Sci., 18, 333-341, doi:10.5194/hess-18-333-2014, 2014.

Dann, R., Bidwell, V., Thomas, S., Wöhling, T., and Close, M.: Modeling of nonequilibrium bromide transport through alluvial gravel vadose zones, Vadose Zone J., 9, 731-746, doi:10.2136/vzj2009.0127, 2010.

Dann, R., Thomas, S., Waterland, H., Flintoft, M., and Close, M.: Nitrate and nitrous oxide dynamics under urine application in an alluvial gravel vadose zone, Vadose Zone J., 12, doi:10.2136/vzj2012.0038, 2013.

Doltra, J. and Muñoz, P.: Simulation of nitrogen leaching from a fertigated crop rotation in a Mediterranean climate using the EURotate_N and Hydrus-2D models, Agric. Water Manage., 97, 277-285, doi:10.1016/j.agwat.2009.09.019, 2010.

Edition, F.: Guidelines for Drinking-water Quality, WHO chronicle, 38, 104-108, 2011.

European Community: Council directive concerning the protection of water against pollution caused by nitrates from agricultural sources, Official Journal of the European Community (91/676/EEC), Legislation 1375/1-375/8, European Community, 1991.

Elhanany, S.: Challenges in preserving the quality of water resources in Israel, The Jerusalem Conference for Environment and Nature, Jerusalem (in Hebrew), 2009.

Gautam, S. and Iqbal, M. Z.: Using stable isotopes of nitrogen to study its source and transformation in a heavily farmed watershed, Environ. Earth Sci., 60, 11-20, doi:10.1007/s12665-0090165-7, 2010.

Green, C. T., Fisher, L. H., and Bekins, B. A.: Nitrogen fluxes through unsaturated zones in five agricultural settings across the United States, J. Environ. Qual., 37, 1073-1085, doi:10.2134/jeq2007.0010, 2008.

Hanson, B. R., Šimůnek, J., and Hopmans, J. W.: Evaluation of urea-ammonium-nitrate fertigation with drip irrigation using numerical modeling, Agric. Water Manage., 86, 102-113, doi:10.1016/j.agwat.2006.06.013, 2006.

Herridge, D., Peoples, M., and Boddey, R.: Global inputs of biological nitrogen fixation in agricultural systems, Plant Soil, 311, 1-18, doi:10.1007/s11104-008-9668-3, 2008.

Israel Meteorological Service: Web Israel Meteorological Service: data base, available at: http://data.gov.il/ims-results, last access: 1 December 2015.

Israel Water Authority: Web Israel Water Authority: Professional Information and Data/Water-Quality (in Hebrew), available at: http://www.water.gov.il/Hebrew/ProfessionalInfoAndData/ Water-Quality/DocLib1/kolhin-seker2012.pdf, last access: 1 April 2016.

Kendall, C. and McDonnell, J. J. (Eds.): Isotope Tracers in Catchment Hydrology, Elsevier Science, Amsterdam, 1998.

Kurtzman, D., Shapira, R. H., Bar-Tal, A., Fine, P., and Russo, D.: Nitrate fluxes to groundwater under citrus orchards in a Mediterranean climate: observations, calibrated models, simulations and agro-hydrological conclusions, J. Contamin. Hydrol., 151, 93 104, doi:10.1016/j.jconhyd.2013.05.004, 2013.

Liao, L., Green, C. T., Bekins, B. A., and Böhlke, J. K.: Factors controlling nitrate fluxes in groundwater in agricultural areas, Water Resour. Res., 48, W00L09, doi:10.1029/2011WR011008, 2012.

Lockhart, K. M., King, A. M., and Harter, T.: Identifying sources of groundwater nitrate contamination in a large alluvial groundwater basin with highly diversified intensive agricultural production, J. Contamin. Hydrol., 151, 140-154, 2013.

Marquardt, D. W.: An algorithm for least-squares estimation of nonlinear parameters, SIAM, J. Appl. Math., 11, 431-441, 1963. 
McIlvin, M. R. and Altabet, M. A.: Chemical conversion of nitrate and nitrite to nitrous oxide for nitrogen and oxygen isotopic analysis in freshwater and seawater, Anal. Chem., 77, 5589-5595, 2005.

Nolan, B. T., Puckett, L. J., Ma, L., Green, C. T., Bayless, E. R., and Malone, R. W.: Predicting unsaturated zone nitrogen mass balances in agricultural settings of the United States, J. Environ. Qual., 39, 1051-1065, doi:10.2134/jeq2009.0310, 2010.

Olson, B. M., McKenzie, R. H., Larney, F. J., and Bremer, E.: Nitrogen- and phosphorus-based applications of cattle manure and compost for irrigated cereal silage, Can. J. Soil Sci., 90, 619635, doi:10.4141/CJSS10026, 2010.

Olson, B. M., Bennett, D. R., McKenzie, R. H., Ormann, T. D., and Atkins, R. P.: Nitrate leaching in two irrigated soils with different rates of cattle manure, J. Environ. Qual., 38, 2218-2228, doi:10.2134/jeq2008.0519, 2009.

Onsoy, Y. S., Harter, T., Ginn, T. R., and Horwath, W. R.: Spatial variability and transport of nitrate in a deep alluvial vadose zone, Vadose Zone J., 4, 41-54, 2005.

Oren, O., Yechieli, Y., Böhlke, J. K., and Dody, A.: Contamination of groundwater under cultivated fields in an arid environment, central Arava Valley, Israel, J. Hydrol., 290, 312-328, doi:10.1016/j.jhydrol.2003.12.016, 2004.

Rimon, Y., Dahan, O., Nativ, R., and Geyer, S.: Water percolation through the deep vadose zone and groundwater recharge: Preliminary results based on a new vadose zone monitoring system, Water Resour. Res., 43, W05402, doi:10.1029/2006WR004855, 2007.

Rimon, Y., Nativ, R., and Dahan, O.: Physical and chemical evidence for pore-scale dual-domain flow in the vadose zone, Vadose Zone J., 9, 1-10, doi:10.2136/vzj2009.0113, 2011.

Rochester, I. J., Peoples, M. B., Hulugalle, N. R., Gault, R. R., and Constable, G. A.: Using legumes to enhance nitrogen fertility and improve soil condition in cotton cropping systems, Field Crops Res., 70, 27-41, 2001.

Salazar, F., Martínez-Lagos, J., Alfaro, M., and Misselbrook, T.: Low nitrogen leaching losses following a high rate of dairy slurry and urea application to pasture on a volcanic soil in Southern Chile, Agr. Ecosys. Environ., 160, 23-28, doi:10.1016/j.agee.2012.04.018, 2012.

Scanlon, B. R., Reedy, R. C., Gates, J. B., and Gowda, P. H.: Impact of agroecosystems on groundwater resources in the Central High Plains, USA, Agr. Ecosys. Environ., 139, 700-713, 2010.

Showers, W. J., Genna, B., McDade, T., Bolich, R., and Fountain, J. C.: Nitrate contamination in groundwater on an urbanized dairy farm, Environ. Sci. Technol., 42, 4683-4688, 2008.

Spalding, R. F., Watts, D. G., Schepers, J. S., Burbach, M. E., Exner, M. E., Poreda, R. J., and Martin, G. E.: Controlling nitrate leaching in irrigated agriculture, J. Environ. Qual., 30, 1184-1194, 2001.
Toride, N., Leij, F. J., and van Genuchten, M. Th.: The CXTFIT code for estimating transport parameters from laboratory or field tracer experiments, Version 2.1, Research Report No. 137, USDA-ARS US Salinity Laboratory, Riverside, CA, USA, 1999.

Toride, N., Inoue, M., and Leij, F. J.: Hydrodynamic dispersion in an unsaturated dune sand, Soil Sci. Soc. Am. J., 67, 703-712, 2003.

Turkeltaub, T., Dahan, O., and Kurtzman, D.: Investigation of groundwater recharge under agricultural fields using transient deep vadose zone data, Vadose Zone J., 13, 1-13, doi:10.2136/vzj2013.10.0176, 2014.

Turkeltaub, T., Kurtzman, D., Bel, G., and Dahan, O.: Examination of groundwater recharge with a calibrated/validated flow model of the deep vadose zone, J. Hydrol., 522, 618-627, doi:10.1016/j.jhydrol.2015.01.026, 2015a.

Turkeltaub, T., Kurtzman, D., Russak, E. E., and Dahan, O.: Impact of switching crop type on water and solute fluxes in deep vadose zone, Water Resour. Res., 51, 9828-9842, doi:10.1002/2015WR017612, 2015b.

US EPA: Is your drinking water safe? EPA, Office of Water, publication number 810 F94002, available at: http://www.epa.gov/ nscep/index.html (last access: October 2015), 1994.

Vanderborght, J. and Vereecken, H.: Review of dispersivities for transport modeling in soils, Vadose Zone J., 6, 29-52, 2007.

Van Genuchten, M. T., Šimůnek, J., Leij, F. J., Toride, N., and Šejna, M.: STANMOD: model use, calibration and validation, Trans. ASABE, 55, 1353-1366, 2012.

van Grinsven, H. J. M., ten Berge, H. F. M., Dalgaard, T., Fraters, B., Durand, P., Hart, A., Hofman, G., Jacobsen, B. H., Lalor, S. T. J., Lesschen, J. P., Osterburg, B., Richards, K. G., Techen, A.-K., Vertès, F., Webb, J., and Willems, W. J.: Management, regulation and environmental impacts of nitrogen fertilization in northwestern Europe under the Nitrates Directive; a benchmark study, Biogeosciences, 9, 5143-5160, doi:10.5194/bg-9-5143-2012, 2012.

Westerman, P. W. and Bicudo, J. R.: Management considerations for organic waste use in agriculture, Bioresour. Technol., 96, 215221, 2005.

Wassenaar, L. I., Hendry, M. J., and Harrington, N.: Decadal geochemical and isotopic trends for nitrate in a transboundary aquifer and implications for agricultural beneficial management practices, Environ. Sci. Technol., 40, 4626-4632, 2006.

Zhang, Y., Li, F., Zhang, Q., Li, J., and Liu, Q.: Tracing nitrate pollution sources and transformation in surface-and ground-waters using environmental isotopes, Environ. Sci. Technol., 490, 213 222, doi:10.1016/j.scitotenv.2014.05.004, 2014. 